\title{
Between the United States and the People's Republic of China. The dilemma of the European Union's negotiation position in the context of the accelerated technological development of the PRC ${ }^{1}$
}

After the 2008 global economic crisis and overwhelming criticism of global capitalism in its neoliberal version, the People's Republic of China is clearly posing as a new leader in globalization processes. The Chinese President Xi Jinping emphasized this most clearly during the 47th World Economic Forum (WEF) summit in Davos in 2017. It was not a coincidence that his speech opened this summit. In the absence of Donald Trump, President Xi warned that "[n]o one will emerge as the winner in a trade war" if the world rejects globalization and decides to block international trade. He referred in his speech to the protectionist and unilateral trends seen in the policies of other states, and in particular to the election promises of the then president-elect of the United States, who threatened to accuse China of manipulating its own currency, harmful trade practices and to implement relevant investigations and procedures. In reply to this, President Xi emphasized that "the problems troubling the world are not caused by economic globalization," and added that the benefits it has generated should not be denied but "we should [...] cushion its negative impact." The Chinese leader argued that in this decision-making process "[e]merging markets and developing countries deserve greater representation and voice."

The New York Times described the 2017 WEF summit and the Chinese position presented there as a 'tectonic change.' For almost half a century, the Swiss resort had mainly been a venue where Americans and Europeans met, and who dominated both its formula and agenda. The slogan of the 2017 edition of the forum was 'responsible leadership,' which clearly corresponded to the new official Chinese development strategy. ${ }^{2}$ The paradox of the new Chinese development paradigm is that the state that has

${ }^{1}$ The article was written as part of a project co-founded by the Erasmus + Programme of the European Union "Jean Monnet Center of Excellence EU EX/ACT-EU External Actions in the contested global order - (in)coherence, (dis)continuity, resilience".

DISCLAIMER: The European Commission support for the production of this publication does not constitute an endorsement of the contents which reflects the views only of the authors, and the Commission cannot be held responsible for any use which may be made of the information contained therein.

${ }^{2}$ Emphasizing the advantages of the new Chinese vision of the global economic order, the Chinese leader prefers to use the term 'proponent of globalization,' (rather than 'leader'), sometimes failing to mention that it is about globalization on the new, Chinese terms. For more see Xi Jinping w Davos..., 2017. 
long been known for its interventionism and protectionism (which it has never completely abandoned) currently considers it fundamental in trade policy today to prevent the rise of protectionism in the United States and the European Union. While presenting itself as a champion of globalization, the Chinese authorities do not publicly declare that in fact they are talking about 'globalization on Chinese terms' of full openness to fair competition on all global markets... except for their own. China has long sought to limit opposition from the United States and Europe against the dominant role of the state in stimulating China's economic growth, manifested, for example, by supporting exporters with preferential loans and credit and subsidizing state enterprises.

The European Union and the United States apparently have serious grounds for criticizing China's economic policy for many other reasons as well. Discriminatory laws and practices, such as forcing foreign investment to be made in the form of joint ventures and technology transfers ('forced technology transfer'), difficult access for foreign companies to public procurement, limited access to the service market, violation of intellectual property rights, dumping in salaries and social benefits, as well as the fixed, non-market exchange rate of the yuan are further examples of Chinese authorities' activities that can, or actually should be criticized by other countries, including EU institutions and member states (Pyffel, 2012; Kłaczyński, 2017). ${ }^{3}$ Chinese trading practices, and especially how they acquire the latest technologies, have triggered retaliatory steps by the United States. In April 2018, the US administration presented a list of over a thousand Chinese products to have 25-percent tariffs imposed. These tariffs are a punishment for the PRC's policy of forcing American companies operating in China to transfer their technologies to local partners, and for hacking attacks on the servers of cutting-edge American companies and stealing their intellectual property. According to the US trade representative Robert Lighthizer, the list includes products whose imports to the United States are valued at nearly $\$ 50$ billion a year. According to China, the US actions may be a violation of international trade rules. The PRC Ministry of Trade described them as "typical unilateral and protectionist practices that China strongly condemns and firmly opposes" (Wojna handlowa USA i Chin..., 2018). On the other hand, the European Union believes that such steps should always be taken on the basis of multilateral regulations, preferably those of the World Trade Organization, which has a number of instruments available to effectively solve similar problems in trade. The new tariffs for Chinese products are to be targeted especially at the products covered by the Made in China 2025 economic strategy. The list in-

3 As emphasized by Michał Kłaczyński (LL.M.) from Harvard, a lawyer with extensive experience in international economic law, joint ventures have remained the basic mechanism of foreign investment in China for over forty years. In his opinion, despite the passage of time, almost half of such contracts are still poorly negotiated by European investors and, as a consequence, the operations of such companies are unsuccessful. This is because Europeans unquestioningly assume that Chinese company law is similar to their domestic laws. Yet European and American investors focus on ownership control, while Chinese investors always focus on operational control. As a result, a European investor finances a company that theoretically belongs to him, but in fact has no influence on its dayto-day operations or management. There is also the risk of embezzlement and loss of control over the use of technology. Hence, as early as the stage of a preliminary contract with a Chinese partner, European investors should secure their own interests. The agreements on confidentiality, technology protection, trademark rights and non-competition are important in this case. An alternative exit scenario should also be prepared in advance to withdraw from potentially unsuccessful cooperation. 
cludes high resolution monitors, electromagnets for MRI, components of devices used in aviation and machines for the production or processing of textiles or food among other things (Ibid.).

The planned US penalty tariffs and Chinese retaliation tariffs are part of the growing trade tensions between the two largest economies in the world. China announced the introduction of 15- and 25-percent tariffs on 128 US goods valued at $\$ 3$ billion a year, including frozen pork, fruit, wine and steel pipes. This was a response to American tariffs earlier imposed on steel and aluminum. Many countries were temporarily excluded from these tariffs, but this did not apply to China. The Chinese authorities deny the US allegations and condemn trade retaliation (Ibid.).

Although Donald Trump's accusations against China are often exaggerated for media purposes, they are deeply justified. For many years, China has forced western investors to transfer the latest technologies, which was a condition to allow foreign corporations to enter the enormous Chinese market. In many industries, the share of a foreign investor in China cannot exceed 50 percent, and Chinese companies, even private ones, are heavily controlled by the state. The protection of intellectual property, especially in the case of foreign corporations, is illusory, as is China's compliance with other WTO rules. Forced technology transfer and unauthorized access to foreign technology are among the reasons why Chinese subsidized state-owned enterprises are rapidly catching up with the world's technological leaders. The sanctions imposed in May 2018 by the United States on the world's second largest mobile phone manufacturer and one of the leaders in 5G technology, the Chinese concern Huawei, have become one of the more visible manifestations of this problem. According to a White House statement, Donald Trump's order aims to "protect America from foreign adversaries who are actively and increasingly creating and exploiting vulnerabilities in information and communications technology infrastructure and services." It gives the Secretary of Commerce the power to "prohibit transactions posing an unacceptable risk to the national security," the statement says (Ibid.; Simonite, 2019; Huawei: China threatens..., 2019).

Foreign corporations and many governments worldwide have long allowed this, counting on large profits from the sale of their products on the gigantic Chinese market and profits from exporting products manufactured in China at much lower cost. The US administration imposing tariffs and other trade restrictions was well aware that China would retaliate, which it has done, threatening to further escalate the conflict. However, the US administration believes that China has more to lose, due to the significant imbalance in foreign trade. In 2017, the exports of US corporations to China amounted to $\$ 130.4$ billion, which was one fourth of US imports. In mid-2019, the American economy was accelerating while the Chinese economy was slowing down, which makes the American actions sensible, at least temporarily. Many renowned academics and experts agree that it is necessary to force China to apply equal trade conditions. The dispute is rather about how to achieve this (Ibid.).

For example, in the opinion of Martin Feldstein, a Professor of Economics at Harvard University, President Emeritus of the National Bureau of Economic Research, and the chairman of President Ronald Reagan's Council of Economic Advisors in 1982-1984: "the Chinese violate their WTO obligations by requiring foreign firms 
that do business in China to have a domestic partner and to transfer technology to that firm. But the US did not wait for a WTO ruling to confirm its claim and to authorize the imposition of tariffs as a penalty for China's rules violation. Nor has the US said that it would end the tariffs if the Chinese rescinded their illegal technology-transfer requirement. Chinese officials say their policy is clear: American firms can have access to the Chinese market only if they contribute their technology in return. But this policy is explicitly prohibited by the WTO and is not a policy that other countries pursue. [...] I think policymakers should make it clear to the Chinese that the US would end its tariffs if the Chinese stopped stealing American firms' technology. This would include the Chinese policy of requiring US firms to transfer technology to Chinese partners as a condition of doing business in China, as well as the Chinese practice of taking technology directly from US firms through cyber espionage and other illegal methods. The Chinese government agreed to end government cyber theft of industrial technology when then-President Barack Obama met Chinese President Xi Jinping in 2013 and showed the evidence of such activity by the People's Liberation Army. But that agreement didn't cover theft by state-owned enterprises and private firms. Negotiations should cover all forms of technology theft" (Feldstein, 2018).

Political relations between the People's Republic of China and the United States therefore have remained cold, and this is not since the beginning of Trump's presidency. Jonathan Fenby in his study Will China Dominate the 21st Century? accurately points out that there is ample evidence to support the thesis that none of the parties has trusted the other one in political or socioeconomic terms for a long time now. The 2013 survey shows that over two years, the percentage of Americans expressing positive opinions about China dropped from 51 to 37 percent, while the number of Chinese speaking amicably about the United States decreased from 58 to 40 percent. Admittedly, talking to the US President Barack Obama at the California Summit in mid-2013, President Xi compared his 'Chinese dream' to the 'American dream,' but it can be easily seen that both concepts are fundamentally different because they are based on a principally different value system and a different perception of the future of the world. The idea of two closely cooperating powers, commonly called 'Chimerica,' is not very likely to become a global reality any time soon, although the exceptional unpredictability of the US President Donald Trump makes also this matter unclear. Americans do not hide their concerns about the growing economic importance of China in the world and the methods China uses to secure its dominance. These concerns are also about the growing trade deficit and its causes, the loss of jobs due to the transfer of American production to the PRC, the Chinese mercantilist approach to the sphere of international trade, and Chinese practices bordering on breaking the law: from currency manipulation, through disrespect for intellectual property rights, to cyber espionage. ${ }^{4}$

The European Union has also responded to non-transparent Chinese practices, albeit in a definitely more balanced manner than the United States. The US President has accused China of unfair trading practices and forced technology transfer in exchange for access to its domestic market. European companies have long complained about this, too. Therefore, the European Commission announced that the EU and China

\footnotetext{
${ }^{4}$ For more see: Fenby 2014.
} 
would establish a group to update the rules of international trade. In the opinion of Jyrki Katainen, Vice President of the European Commission, the unilateral actions of US President Donald Trump towards China in trade disputes over steel and steel products, unauthorized access to technology and in other matters, have showed above all that the World Trade Organization should urgently reform its activities. He also urged China to reduce market access barriers for European companies and deal with the problem of steel overcapacity. He also mentioned the concerns related to China's economic strategy Made in China 2025, under which domestic high-tech companies receive significant and unauthorized government subsidies. In the opinion of most EU companies operating in China, Chinese companies have better access to the EU market than European companies to the Chinese market (Europa i Chiny chca..., 2018; Ctami $w$ deficyt..., 2018).

At this point, it is worth taking a closer look at the Chinese plans to modernize their domestic economy which are arousing so many fears. The Chinese are known for thinking in the long term, and implementing many dimensions of their policies gradually. The foundation of a new type of their innovative economy is laid out in a strategic document entitled the Medium- and Long-Term Plan on the Development of Science \& Technology 2006-2020. It envisages strengthening of what is called indigenous innovation (自主 创新) which will ultimately eliminate the very strong dependence of the Chinese economy on the import of foreign technologies and know-how, as well as Western corporations investing in China. Such a high dependence of export production in modern manufacturing sectors on foreign enterprises has gradually caused frustration in China. It has resulted from the Chinese market development policy failing to automatically translate into the absorption of knowledge and technology by domestic enterprises and the improvement of their development capacity in creating their own innovative solutions. Moreover, the Chinese expanding culture of imitating and copying has embraced more than product design and development and is also almost universally found in the field of scientific research. Therefore, the need for innovation and intellectual property has become increasingly clear, which should come from native Chinese business entities (Starzyk, 2013). Simultaneously, China is also planning to increase R\&D expenditure to $2.5 \%$ of GDP by 2020 , increase the share of science and technology in economic development to a level of at least 60 percent and reduce dependence on foreign technologies to 30 percent (Ibid.).

According to the Long-Term Plan on the Development of Science \& Technology, research areas such as biotechnology, genetic engineering, renewable energy sources (especially solar energy), information and communication technologies, aviation and space technologies, nanotechnologies and synthetic materials would be prioritized until 2020. At the same time, the development of institutions is planned for the purpose of facilitating innovative activities, increased use of financial and fiscal instruments for innovative companies and strengthened protection of intellectual property (also with the intention of protecting the interests of innovative national companies) (Zorska, Molęda-Zdziech, Jung, 2014). ${ }^{5}$

${ }^{5}$ The Chinese authorities perceive scientific and technological progress as a key factor to enable further rapid economic development of their country and help solve the great social, health, ecological and energy problems facing it. It is China's official goal to become an innovative economy by 
The fifteen-year strategy of the technological development of China, or the Medium- and Long-Term Plan on the Development of Science \& Technology 2006-2020, is to ensure that the Chinese economy reaches the aforementioned level of indigenous innovation (自主 创新). Unlike the Made in China 2025 program, which is its development and a kind of continuation, discussed further in this article, the strategy focuses almost exclusively on technologically advanced industries (with the exception of agriculture) classified in eleven priority development areas - strategic emerging industries (战略性 新兴 产业). Sixty-eight issues in which significant technical progress is to occur are indicated. In addition, the 2006-2020 plan assumes the implementation of 16 major research projects, research on 27 pioneering technologies in eight selected fields and 18 priorities in the field of basic research. ${ }^{6}$

Through the implementation of the above strategies, China is seeking to become independent of foreign technologies. The Chinese are increasingly focusing on the development and implementation of their own modern solutions, building an adequate scientific and research base, and greater recognition of their own brands. These premises will be continued after 2020 as provided in a new Chinese technological self-sufficiency plan in industry, strongly promoted globally under the name of Made in China 2025. When preparing it, the Chinese were perfectly aware that basically all developed economies in the world were introducing innovative solutions, such as artificial intelligence (AI), three-dimensional printing, fast $5 \mathrm{G}$ mobile Internet, the Internet of Things, cognitive computing (CC), cloud computing, Big Data, bioengineering, autonomous robots and vehicles, new energy sources and new materials. They also understand very well that the mass application of new generation information technologies, which are the manifestation of the fourth industrial revolution, leads to profound industrial changes, contributes to the emergence of new production methods and business models, and ultimately drives economic growth. China is currently facing a great opportunity to modernize and transform its manufacturing sector, moving towards smart production. The Chinese are hoping that, due to the implementation of the program, the simultaneous development of new types of industrialization, urbanization and computerization in both industry and agriculture, the domestic demand that has been suppressed so far will increase (Made in China 2025 《中国制造 2025》 ..., 2017). ${ }^{7}$ The frustration of the United States and the European Union is not a result of China implementing measures to develop its native innovations, which is understandable, but of the methods through which the Chinese authorities want to achieve this goal.

EU institutions, with the Commission and Parliament at the helm, reasonably emphasize that the PRC is, and should be seen as a country with one of the largest and most promising markets in the world. Despite the economic slowdown, the European Union, at the level of both Community institutions and the governments of member states, still sees huge development potential in China. The mutual economic significance of both entities is enormous and cannot be downplayed. There are also analyses

2020 , and one of the global leaders in research by 2050 . R\&D expenditure is forecasted to increase from 1.6 percent to 2.5 percent of GDP by the end of this decade, and the contribution of technological progress to economic development is expected to reach 60 percent.

${ }^{6}$ For more see: Starzyk, 2013.

${ }^{7}$ For more on the plan premises see also: Shao, 2017. 
demonstrating that, despite noticeable barriers and development problems, China will remain the growth leader among emerging markets. This is confirmed by, among others, Chris Davies, CEO of Europe International HSBC, in whose opinion "the incomes and mobility of PRC citizens are increasing, there are more and more tourists, and the economy is constantly growing, despite the visible slowdown. That is why it is advisable to ensure closer cooperation with China." According to HSBC calculations, over the next few decades, the income of an average Chinese employee may increase up to seven times (from $\$ 2,500$ in 2012 to $\$ 18,000$ in 2050) (Davies, 2014).

The European Union and China have much in common. Their GDPs ( $€ 14.72$ trillion and $€ 9.75$ trillion, respectively, in 2015) rank number two and number three in the world, behind the United States ( $€ 16.64$ trillion). They are two of the most externally-integrated economies in the world, with annual international trade in goods and services of $€ 15$ trillion ( $€ 5$ trillion if only trade external to the EU is considered) and $€ 4.75$ trillion, respectively, in 2015. Their annual bilateral trade in goods and services stood at $€ 580$ billion in 2015, with each being the other's largest source of imports and second-largest export destination. Both EU and Chinese leaders believe that effective rules-based multilateralism should form the core of global governance. The two are also not security competitors. Trade in goods has been the driving force in the EU-China economic relationship (García-Herrero, Kwok, Xiangdong, Summers, Yansheng, 2017).

The problems with the mutual understanding of competition rules in global trade have had a long history. In October 2010, the then EU Trade Commissioner Karel De Gucht presented his standpoint in this respect. He implied that the European Union would start working on firm measures to enforce reciprocity in allowing Western investments (discriminated against in public procurement and elsewhere) in China, and commence a serious fight against intellectual property theft - mass counterfeiting of Western products (which is irritating, especially as Chinese patents are strictly protected in the EU). "For several years, the Union pursued a policy of attracting Beijing unconditionally and failed completely. We opened our arms in the hope that they would slowly adopt our political and economic models. Meanwhile, Chinese investors are booming in Europe, while European investors are often brushed off from China. And let's not even mention concessions in the field of human rights" said François Godement, expert of the European Council on Foreign Relations (Bielecki, 2010; Chińska waluta..., 2010). This specific fight for reciprocity in investor relations could take an extreme form of EU sanctions, i.e. the threat of closing the Single Market for Chinese producers in the same sectors that are closed to European entrepreneurs in China (Ibid.). "Europeans have no choice but to look for a way to prevent Chinese expansion from marginalizing them in the global economy," experts from The Conference Board, Inc. warned in June 2010. "The current advantage of the European Union, achieved due to the development of mid-market segment technology, is not enough. The European service sector must also be more competitive, but, above all, larger expenditures must be allocated to the development of the most advanced technologies and their protection, development of innovation and education" this renowned business organization, with an analytical and research profile, suggested (Ibid.).

The European Commission also issued an opinion on this matter. Over a decade ago, in delicate and eminently diplomatic language, it pointed out that China, which 
benefited greatly from participating in the international trade system, should bear greater - commensurate - responsibility for the global economic order. In 2006, the Commission emphasized in a special communiqué that China should open its markets and ensure conditions of fair market competition. In the opinion of the European Commission, the main challenge for EU trade policy in the coming decade will be to meet the challenges of competition and develop favorable conditions for trade with China (Komisja Wspólnot Europejskich, 2006).

The following two years demonstrated that the appeals of the EU institutions were far from effective, and the European irritation with the lack of equal trade relations with China was rapidly growing. In 2007, in a confidential letter to the President of the Commission, José Manuel Barroso, which 'accidentally' leaked into the press, the then Trade Commissioner, Peter Mandelson, wrote: "To some extent the Chinese juggernaut is out of control," and the European Union should react firmly because it was sitting on a "policy time bomb." State interventionism, trade barriers maintained by the Chinese side as well as forced technology transfers and unauthorized access to know-how was becoming increasingly burdensome and harmful for European partners. ${ }^{8}$ Cooperation with European companies allowed Chinese companies to acquire new technologies and know-how, and these 'forced technology transfers' proved to be an excellent tool for improving the innovation of Chinese enterprises that were subsidized and were increasingly interested in acquiring the best European high-tech companies. The European Commission emphasized that the PRC's accession to the WTO did not ensure fully liberalized access to the Chinese public procurement market, fully transparent and fair trade rules (numerous dumping practices), adequate protection of intellectual property rights or the elimination of public subsidies granted to concerns interested in mergers and acquisitions (M\&A) in Europe. Trade exchange with the EU and large EU trade deficit in relations with the PRC undoubtedly contributed to the further strengthening of China's already strong competitive position in the world (Gomółka, BorucińskaTereszkiewicz, 2016). The new EU strategy towards China was presented in 2016. It remains an important, top-level joint document setting directions for the development of a 'comprehensive strategic partnership' and boundary conditions for cooperation. ${ }^{9}$

It seems obvious that the United States is stepping back from playing the lead role in supporting more open global markets, and there are profound concerns across the world about the negative impacts of globalization on income inequality. This overall shift makes it an especially important moment for the EU and China to consider how to deepen the full range of their bilateral economic relationship - by increasing trade and investment, promoting cooperation in the areas of climate change, energy and the environment, and global governance, collaborating in science, technology and innovation, infrastructure, and financial services, and engaging in people-to-people exchanges. These efforts can be mutually beneficial - they help to sustain economic growth, create jobs and improve levels of social welfare not only within their own societies but also globally. However, elevating the EU-China economic relationship into the genuine strategic partnership envisaged by EU and Chinese leaders will require greater effort from both sides. On the one hand, many EU business leaders perceive Chinese

\footnotetext{
${ }^{8}$ For more see: Kamiński, 2014.

${ }^{9}$ For more see: Komisja Europejska, 2016.
} 
companies as sources of unfair competition, in both the EU and Chinese markets. On the other hand, Chinese companies worry that the EU may impose policy measures against them, such as anti-dumping and countervailing duties, which are perceived in China as unfair (García-Herrero, Kwok, Xiangdong, Summers, Yansheng, 2017).

The most recent, 20th Summit between the European Union and the People's Republic of China, held on July 16, 2018 in Beijing, underlined that this partnership had reached a new level of importance for EU and Chinese citizens, for respective neighboring regions and for the international community more broadly. "I have always been a strong believer in the potential of the EU-China partnership. And in today's world that partnership is more important than ever before. Our cooperation simply makes sense," said the President of the European Commission, Jean-Claude Juncker. "Europe is China's largest trading partner and China is our second largest. The trade in goods between us is worth over $€ 1.5$ billion every single day. But we also know that we can do so much more. This is why it is so important that today we have made progress on the Comprehensive Agreement on Investment through a first exchange of offers on market access, and towards an agreement on Geographical Indications. That shows that we want to create more opportunities for people in China and in Europe," emphasized the President of the European Commission (EU-China Summit..., 2018). ${ }^{10}$

In the opinion of both negotiating parties, the Joint Summit Statement agreed by the European Union and China illustrates the breadth and depth of EU-China relationship and the positive impact that such a partnership can have, in particular when it comes to addressing global and regional challenges such as climate change, common security threats, the promotion of multilateralism, and the promotion of open and fair trade. At the Summit, the EU and China confirmed their firm support to the rules-based, transparent, nondiscriminatory, open and inclusive multilateral trading system with the WTO as its core, and committed to complying with existing WTO rules. They also committed to co-operating on the reform of the WTO to help it meet new challenges, and established a joint working group on WTO reform, chaired at vice-ministerial level, to this end. Good progress was made on the ongoing Investment Agreement negotiations, which is a top priority and a key project towards establishing and maintaining an open, predictable, fair and transparent business environment for European and Chinese investors (Ibid.).

${ }^{10}$ EU Vice-President Katainen and the Minister of Ecology and Environment, Li Ganjie, also signed the Memorandum of Understanding to Enhance Cooperation on Emissions Trading, which acknowledges the significant potential of emissions trading to contribute to a low carbon economy and further enhances the cooperation of the two largest emission trading systems of the world. Building on the success of the 2017 EU-China Blue Year, the EU and China have also signed a Partnership Agreement on Oceans. Vice-President Katainen and the Chairman of the National Development and Reform Commission, He Lifeng, also signed the Memorandum of Understanding on Circular Economy Cooperation that will provide a framework for cooperation, including a high-level policy dialogue, to support the transition to a circular economy. The EU and China have also signed the Action Plan Concerning China-EU Customs Cooperation on Intellectual Property Rights (2018-2020), with the aim of strengthening customs enforcement to combat counterfeiting and piracy in the trade between the two. Finally, The European Anti-Fraud Office (OLAF) and the General Administration of China Customs signed a Strategic Administrative Cooperation Arrangement and an Action Plan (2018-2020) on strengthening the cooperation in combatting customs fraud in particular in the field of transshipment fraud, illicit traffic of waste and undervaluation fraud. 
Further cooperation, described as a strategic European-Chinese partnership is, however, conditional and one of the most important elements on the Chinese side to eliminate is the problem of forced technology transfers. On July 16, 2018, the European Union challenged in the World Trade Organization the systemic practices that force European companies to give up sensitive technology and know-how as a precondition for doing business in China. This legal action builds upon a case launched by the EU in June 2018. With this move, the EU is significantly broadening and deepening the scope of its WTO action against Chinese measures on forced technology transfers. This step is taken in light of additional findings concerning the incompatibility of the Chinese measures on the approval of investments and the protection of foreign companies' intellectual property rights with the agreed multilateral rules. Commissioner for Trade Cecilia Malmström said: "We cannot tolerate that EU companies have to give away valuable technology as a price to pay for investing in China. This clearly goes against the rules that China committed itself to when it joined the WTO. Today, we launch a broader and more systemic legal challenge against this illegal practice, as we believe that it is a major issue affecting European companies doing business in China. This is a matter that can and should be solved within the international, multilateral framework" (EU steps up..., 2018). ${ }^{11}$

The growing antagonisms on the Washington-Beijing line, which were only slightly eased in June 2019 during the G-20 summit in Osaka, are triggering Chinese interest in closer cooperation with the European Union. On the level of political declarations, China treats the European Union as one of the three most important 'global players/actors' (next to the United States and the Russian Federation). The Chinese describe their relations with the EU as one of the most important bilateral relations in the modern world and as 'a comprehensive strategic partnership for mutual benefit and cooperation.' The EU is also regularly appreciated in Chinese rhetoric as an important global partner and key player in building a multipolar international order. However, both official documents and declarations made by Chinese leaders reflect the actual perception of integrated Europe by the political elites only to a small extent. The facts indicate that these analysts (for instance those from the Warsaw Center for Eastern Studies) who believe that China perceives Europe as an important but weakening actor on a global scale are right. China has a sense of its own advantage over both the poorly coordinated European Union, with its inconsistent decision-making and its individual member states, which are skillfully 'played out' by China, under separate $17+1$ formats or separately agreed bilateral agreements. The Chinese side is therefore fully aware that there is neither a common nor a more coherent European policy towards China. China also rightly notes that the level of criticism towards its own actions is much lower in Europe than in the United States. This is particularly true about new EU member states from

${ }^{11}$ The so-called performance requirements force or induce European companies to transfer technology to their joint ventures with Chinese partners in exchange for the necessary administrative approvals by the Chinese authorities. Foreign companies are also required to carry out research and development activities in China. At the time of joining the WTO, China committed itself not to impose performance requirements in exchange for investment approvals, and to preserve the contractual freedom of companies in China, in particular in the context of investments and technology transfers. The EU maintains therefore that the Chinese current policy measures are in violation of China's legal commitments. 
Central and Eastern Europe (and in the future - from Western Balkans), which are to become the 'Chinese gateway to Europe.' Internal divisions in Europe and a kind of competition for the most privileged economic relations with China further strengthen China's sense of strength and advantage over the EU (Kaczmarski, Jakóbowski, 2016; USA czasowo tagodza..., 2019). ${ }^{12}$

Without doubt, in economic terms, Europe is of key importance for China. This is particularly evident in exports, FDI and associated technologies, know-how, as well as the use of China's own currency reserves. Mutual economic interests are generally seen in China as complementary. It is briefly said in China that 'Europe has technologies and China has a receptive internal market.' The Chinese elite sees cooperation with Europe as fundamentally important both for the strategy of further economic expansion in the world to succeed and for the advantage of the Chinese development model to be demonstrated. According to the Chinese elite, the attractiveness of the European economic model, the EU's economic position and its influence in the world has decreased since 2008. Since the eurozone crisis, the Chinese political elite has treated the European Union as a warning, rather than a role model. On the other hand, China does not want European disintegration or the collapse of European integration. Cooperation with a strong (but not too strong) Europe is also necessary to improve China's position in the international division of labor and to lend credence to China's activities in global economic governance. It also helps to soften China's image and create a positive picture of this country in the world. Support from the European Union may also facilitate the success of the internationalization of the yuan, which is highly important for China (Kaczmarski, Jakóbowski, 2016).

It can be concluded that a fundamental issue facing an integrated Europe at the level of Community institutions and governments of member states in the coming years will be answering the question of whether the $\mathrm{EU}$ is able to sacrifice a traditional political, military and economic alliance, and shared values (an axiological alliance) with the United States for closer cooperation with the PRC. Of course, the incumbent US president has already happened to call the European Union an enemy, and the international trade system, whose pillar is the World Trade Organization that enjoys the support of the EU, as harmful to the US and the global economy. China, as already highlighted, is offering a strategic partnership to Europe, while, at least formally, recognizing the importance of the WTO and wishing to support its functioning, role and importance. Nevertheless, a united Europe should be very cautious when negotiating with China and neither reject nor suppress it, but set boundary conditions, including the elimination of unfair trade practices and forced technology transfer first and foremost. The duplication of measures

${ }^{12}$ See e.g.: Dong, Wang, Dekker, 2013; Walkowski, 2017. The initiative to establish the Asian Infrastructure Investment Bank (AIIB) has become an excellent illustration of model relations with Europe from the point of view of Chinese interests. China proposed this initiative in 2015. Many European countries, including Poland, applied to join as founding members. In a way they lent credence to this new Chinese vision of global management, promoting and legitimizing the rise of the PRC in the international economic order. The process of their accession to the AIIB was not coordinated at the Community level and occurred under the circumstances of overt political opposition from the United States. Similar doubts related to creating internal divisions in the EU and limiting its unity are raised by the China-supported $17+1$ format of regional cooperation with countries from Central and Eastern Europe and the Western Balkans. 
such as the trade sanctions implemented by the US administration should be treated as a typical 'second best' solution, which poses the threat of a devastating trade war and as an alternative to the best solution involving a strategic agreement based on equal conditions. As reported by Reuters, for some time, China has put pressure on the European Union to build a common front against the trade policy of the Donald Trump administration. According to the news agency, the Chinese authorities even wanted to issue a joint EU-China declaration condemning US sanctions against China in international trade (Słojewska, 2018; Kozieł, 2018; Bellon, 2018)..$^{13}$

For various reasons, China should not replace the United States as the main European partner and ally in the world. For the time being, the European Commission is not sending any such signals. Bruno Hellendorff, an expert in the Egmont Institute think tank, rightly noted: "The EU has recently tried to clearly show the Chinese authorities that whatever is happening in relations with Donald Trump will not strain the strategic transatlantic partnership between Europe and the US" (Ibid.).

At the same time, the EU has great respect for the successes of the Chinese economy, which is justified. China and its growing importance in the world cannot be underestimated, the more so that the mutual importance of both entities is enormous. Based on the EU-China 2020 Strategic Agenda for Cooperation, the EU should build a strategic investment agreement with China. It should also seek to conclude a free trade agreement (FTA), deepen cooperation in energy security and climate protection, science and innovation, and within the financial sector. Given the specifics of the Chinese development model, or the Beijing Consensus, resembling authoritarian state capitalism, it will be much more difficult, if not impossible, to reach an agreement on the issue of enhancing mutual cooperation in global governance and EU approval of China's geopolitical strategy of The Belt and Road Initiative (BRI). In international trade, an EU-China agreement is highly recommended, with at least two caveats, though. Firstly, reaching a mutually beneficial agreement must be unconditionally based on both sides meeting all WTO rules (something that the PRC is currently having serious problems with), and, secondly, this should not be done at the expense of US economic development or the traditional European-American alliance, which, despite the protectionist and unilateral approach of the United States, continues to be the cornerstone of Europe's security and development. ${ }^{14}$

Eliminating the policy of forced technology transfers, unauthorized subsidies to state-owned enterprises in China and suspicions of cyber attacks on the servers of the most modern companies in the world and the critical infrastructure of other countries are examples of actions that should be taken by the Chinese side first. Only eliminating them will open the door further for successful cooperation with the EU (Chiny to dla Unii..., 2017).

${ }^{13}$ Reuters reports that, during meetings in Brussels, Berlin and Beijing, the Deputy Prime Minister Liu He and high-ranking official in the Ministry of Foreign Affairs Wang Yi offered to conclude an economic alliance between the EU and the PRC and open the Chinese economy more to European investment in exchange for a joint anti-American front. To no avail, though.

${ }^{14}$ The lack of political will is worrying, especially on the American side, regarding the renegotiation and signing of the TTIP Trade and Investment Agreement, which could become the largest free trade agreement in the history of the global economy, accounting for 30 percent of international exchange and 20 percent of global investment. 


\section{Bibliography}

Bellon M., Donald kontra Donald. Trump nazwat UE wrogiem. Tusk: to "fake news", https://businessinsider.com.pl/wiadomosci/donald-trump-nazwal-unie-europejska-wrogiem/0150c7w, July 16, 2018.

Bielecki T., Europo, bądź twarda w Chinach, "Gazeta Wyborcza”, October 7, 2010.

Chiny licza na Unię Europejska wobec nakładania przez USA nowych cet, https://www.wnp.pl/ rynki-zagraniczne/chiny-licza-na-unie-europejska-wobec-nakladania-przez-usa-nowychcel,325763_1_0_0.html, June 25, 2018.

Chiny to dla Unii strategiczne wyzwanie, https://www.obserwatorfinansowy.pl/tematyka/makroekonomia/chiny-to-dla-unii-strategiczne-wyzwanie/, October 4, 2017.

Chińska waluta na nowo musi się nauczyć pełzać, "The Economist Newspaper limited", London (26.06-2.07.2010), after: "Rzeczpospolita", June 28, 2010.

Ctami w deficyt, April 17, 2018, https://forsal.pl/artykuly/1116530,clami-w-deficyt.html.

Często zadawane pytania na temat wspólnego komunikatu. Elementy nowej strategii wobec Chin, Bruksela, Komisja Europejska 22 czerwca 2016 r., europa.eu/rapid/press-release_MEMO16-2258_pl.pdf, November 8, 2017.

Davies Ch., CEO Europe International HSBC, Noworoczne (i nie tylko) możliwości, "Forbes”, January 30, 2014.

Dong L., Wang Z., Dekker H. (eds.) (2013), China and the European Union, January 1, Routledge.

EU steps up WTO action against China's forced technology transfers, Brussels, 20 December 2018, European Commission - Press release, http://europa.eu/rapid/press-release_IP-18-6882_ en.htm.

EU-China Summit: deepening the strategic global partnership Beijing, 16 July 2018, European Commission - Press release, http://europa.eu/rapid/press-release_IP-18-4521_en.htm.

Europa i Chiny chca odświeżyć handel międzynarodowy, https://www.forbes.pl/gospodarka/handelmiedzynarodowy-ue-i-chiny-chca-stowrzyc-nowe-reguly $/ 7 \mathrm{kt} 15 \mathrm{wd}$.

Feldstein M., Gra o cta, czyli o co chodzi w polityce handlowej USA wobec Chin, November 9, 2018, https://www.obserwatorfinansowy.pl/forma/rotator/gra-o-cla-czyli-o-co-chodzi-w-politycehandlowej-usa-wobec-chin/.

Fenby J. (2014), Will China Dominate the 21st Century?, Cambridge.

García-Herrero A., Kwok K. C., Xiangdong L., Summers T., Yansheng Z. (2017), EU-China Economic Relations to 2025 Building a Common Future, A Joint Report by Bruegel, Chatham House, China Center for International Economic Exchanges and The Chinese University of Hong Kong, September.

Gomółka K., Borucińska-Tereszkiewicz I. (2016), Polityka Unii Europejskiej wobec Chin: w kręgu wspótpracy i konkurencji, in: Unia Europejska - Chiny. Dziś $i$ w przyszłości, ed. J. Fiszer, PAN, Warszawa.

Huawei: China threatens to retaliate over US sanctions, May 16, 2019, https://www.bbc.com/news/ world-us-canada-48299522.

Kaczmarski M., contributed by: Jakóbowski J. (2016), Niezbędny partner drugoplanowy Europa w polityce Chin $w$ okresie rządów Xi Jinpinga, "Prace OSW", nr 56, Warszawa, April, pp. 5-28.

Kamiński T. (2014), Po pierwsze gospodarka. Narzędzia polityki zagranicznej ChRL wobec Unii Europejskiej, in: Narzędzia polityki zagranicznej Chińskiej Republiki Ludowej, eds. M. Pietrasiak, D. Mierzejewski, K. Żakowski, Łódź.

Kłaczyński M., Polski biznes w Chinach - najczęstsze problemy, www.gochina.gov.pl/files/?id_ plik=224, November 8, 2017. 
Komisja Wspólnot Europejskich, Bruksela, dnia 24.10.2006 r. COM(2006) 631 wersja ostateczna. Komunikat Komisji do Rady i Parlamentu Europejskiego: EU-Chiny: bliższe partnerstwo, większa odpowiedzialność $\{\mathrm{COM}(2006) 632$ wersja ostateczna\}.

Kozieł H. (2018), Chiny proponuja UE antyamerykański sojusz?, July 4.

Made in China 2025 《中国制造 2025, State Council, July 7, 2015, http://www.cittadellascienza.it/ cina/wp-content/uploads/2017/02/IoT-ONE-Made-in-China-2025.pdf, November 5, 2017.

Pyffel R. (2012), contributed by: Centrum Współpracy Gospodarczej Polska-Chiny, PAIiIZ, Biznes w Chinach. Jak osiagnać sukces, Warszawa, December.

Shao Y., Strategic Vision and Outlook of "Made in China 2025", Mizuo Bank, One Mizuho, Industrial and Regional Policies, https:/www.mizuhobank.com/service/global/cndb/economics/ monthly/pdf/R512-0072-XF-0102.pdf, November 5, 2017.

Simonite T., US Sanctions on Huawei may fuel China's plans for its own tech, https://www.wired. com/story/us-sanctions-huawei-fuel-chinas-plan-tech/, May 28, 2019.

Słojewska A., Chiny nie zastapia Stanów Zjednoczonych, https://www.rp.pl/UniaEuropejska/307169913-Chiny-nie-zastapia-Stanow-Zjednoczonych.html, July 16, 2018.

Starzyk K. (2013), Potencjał technologiczny a rozwój gospodarczy. Chiński system innowacji i transfer technologii, "Problemy Gospodarki Światowej”, nr 8, Warszawa, pp. 148-154.

Starzyk K. (ed.) (2013), Potencjat technologiczny a rozwój gospodarczy. Chiński system innowacji i transfer technologii, "Problemy Gospodarki Światowej”, nr 8, Warszawa, pp. 148-154.

USA czasowo łagodza sankcje wobec Huawei. Dostawy będa ,trudne do zastapienia”, May 21, 2019, 13:21, Updated: May 21, 2019, https://forsal.pl/artykuly/1413508, usa-czasowo-lagodza-sankcje-wobec-huawei-dostawy-beda-trudne-do-zastapienia.html.

Walkowski M. (2017), Chiński model rozwoju społeczno-gospodarczego i jego potencjalna adaptacja w Europie. Założenia, cele, uwarunkowania i realizacja tzw. Konsensusu Pekińskiego, „Przegląd Strategiczny”, nr 10.

Wojna handlowa USA $i$ Chin się zaostrza? Pekin zapowiedziat wprowadzenie cet na 128 amerykańskich towarów, w odpowiedzi na działania Waszyngtonu, April 4, 2018, https:// wpolityce.pl/polityka/388849-wojna-handlowa-usa-i-chin-sie-zaostrza-pekin-zapowiedzialwprowadzenie-cel-na-128-amerykanskich-towarow-w-odpowiedzi-na-dzialania-waszyngtonu.

Xi Jinping w Davos: nikt nie wyjdzie zwycięsko z wojny handlowej, http://www.forbes.pl/xi-jinping-w-davos-nikt-nie-wyjdzie-zwyciesko-z-wojny-handlowej, artykuly,210268,1,1.html, November 8, 2017.

Zorska A., Molęda-Zdziech M., Jung B. (eds.) (2014), Kreatywność i innowacyjność w erze cyfrowej. Twórcza destrukcja 2, SGH, Warszawa, pp. 305-306.

\section{Summary}

In the presented article, the author develops an analysis, assessment and forecast with regard to the problems of the innovative development of the PRC and the European Union's response to Chinese methods of obtaining technological advantage over other countries in the world. While presenting and assessing the implementation of China's key strategic documents in this matter, the author juxtaposes the EU response with the policy of trade sanctions against the PRC imposed by the United States during the presidency of D. Trump, outlining likely scenarios for the future.

Key worlds: European Union, China, trade sanctions, technological development 


\section{Pomiędzy Stanami Zjednoczonymi a Chińską Republiką Ludową.}

Dylematy stanowiska negocjacyjnego Unii Europejskiej w kontekście przyspieszonego rozwoju technologicznego Państwa Środka

\section{Streszczenie}

W prezentowanym artykule autor skupia się na analizie, ocenie i prognozie związanej z problematyką innowacyjnego rozwoju ChRL oraz reakcji Unii Europejskiej na chińskie metody uzyskania przewagi technologicznej nad innymi państwami w świecie. Prezentując i oceniając realizację kluczowych dla Chin dokumentów strategicznych w omawianej materii, autor dokonuje porównania reakcji UE z polityką sankcji handlowych wobec ChRL wprowadzonych przez Stany Zjednoczone w okresie prezydentury D. Trumpa, kreśląc prawdopodobne scenariusze na przyszłość.

Słowa kluczowe: Unia Europejska, Chiny, sankcje handlowe, rozwój technologiczny 
